Article

\title{
Activity Guided Isolation of Phenolic Compositions from Anneslea fragrans Wall. and Their Cytoprotective Effect against Hydrogen Peroxide Induced Oxidative Stress in HepG2 Cells
}

\author{
Shuyue He ${ }^{1,+}$, Xiaoyan Cui ${ }^{2,+}{ }^{\dagger}$ Afsar Khan ${ }^{3}$ (D), Yaping Liu ${ }^{1}$, Yudan Wang ${ }^{1,4}$, Qimin Cui ${ }^{1}$, Tianrui Zhao ${ }^{1}$, \\ Jianxin Cao ${ }^{1}$ and Guiguang Cheng ${ }^{1, *(D)}$ \\ 1 Faculty of Agriculture and Food, Kunming University of Science and Technology, Kunming 650500, China; \\ kmlgdx303@163.com (S.H.); liuyaping@mail.kib.ac.cn (Y.L.); sdlcwyd@163.com (Y.W.); \\ 18908742179@163.com (Q.C.); food363@163.com (T.Z.); jxcao321@hotmail.com (J.C.) \\ 2 Foundation Department, Hai Yuan College, Kunming Medical University, Kunming 650106, China; \\ cuixiaoyan910@163.com \\ 3 Department of Chemistry, Abbottabad Campus, COMSATS University Islamabad, \\ Abbottabad 22060, Pakistan; afsarhej@gmail.com \\ 4 National and Local Joint Engineering Research Center for Green Preparation Technology of Biobased \\ Materials, Yunnan Minzu University, Kunming 650500, China \\ * Correspondence: ggcheng@kmust.edu.cn; Tel.: +86-871-65920216 \\ + These authors contributed equally to this work.
}

Citation: He, S.; Cui, X.; Khan, A.; Liu, Y.; Wang, Y.; Cui, Q.; Zhao, T.; Cao, J.; Cheng, G. Activity Guided Isolation of Phenolic Compositions from Anneslea fragrans Wall. and Their Cytoprotective Effect against Hydrogen Peroxide Induced Oxidative Stress in HepG2 Cells. Molecules 2021, 26, 3690. https:// doi.org/10.3390/molecules26123690

Academic Editors: Višnja Stepanić and Marta Kučerová-Chlupáčová

Received: 29 April 2021

Accepted: 13 June 2021

Published: 17 June 2021

Publisher's Note: MDPI stays neutral with regard to jurisdictional claims in published maps and institutional affiliations.

Copyright: (c) 2021 by the authors. Licensee MDPI, Basel, Switzerland. This article is an open access article distributed under the terms and conditions of the Creative Commons Attribution (CC BY) license (https:/ / creativecommons.org/licenses/by/ $4.0 /)$.

\begin{abstract}
Anneslea fragrans Wall., commonly known as "Pangpo Tea", is traditionally used as a folk medicine and healthy tea for the treatment of liver and intestine diseases. The aim of this study was to purify the antioxidative and cytoprotective polyphenols from A. fragrans leaves. After fractionation with polar and nonpolar organic solvents, the fractions of aqueous ethanol extract were evaluated for their total phenolic (TPC) and flavonoid contents (TFC) and antioxidant activities (DPPH, ABTS, and FRAP assays). The $n$-butanol fraction (BF) showed the highest TPC and TFC with the strongest antioxidant activity. The bio-guided chromatography of BF led to the purification of six flavonoids (1-6) and one benzoquinolethanoid (7). The structures of these compounds were determined by NMR and MS techniques. Compound 6 had the strongest antioxidant capacity, which was followed by 5 and 2 . The protective effect of the isolated compounds on hydrogen peroxide $\left(\mathrm{H}_{2} \mathrm{O}_{2}\right)$-induced oxidative stress in HepG2 cells revealed that the compounds 5 and $\mathbf{6}$ exhibited better protective effects by inhibiting ROS productions, having no significant difference with vitamin C ( $p>0.05)$, whereas 6 showed the best anti-apoptosis activity. The results suggest that $A$. fragrans could serve as a valuable antioxidant phytochemical source for developing functional food and health nutraceutical products.
\end{abstract}

Keywords: Anneslea fragrans; antioxidant; guided isolation; oxidative stress; flavonoid glycosides

\section{Introduction}

Reactive oxygen species (ROS) are produced as by-products though oxidative respiration in normal physiological and biochemical processes [1]. As endogenous free radicals, ROS plays an important role in cell signaling and the maintenance of body constancy in a normal range [2]. If the ROS could not be effectively scavenged, excessive ROS could lead to the occurrence of oxidative stress, which may influence cell proliferation and apoptosis [3]. Oxidative stress is closely related to a variety of diseases including diabetes, hyperlipemia, obesity, cancer, and cardiovascular and neurodegenerative diseases [4]. Recently, many studies have evidenced that a diet enriched with antioxidants possesses a series of beneficial effects owing to their scavenging ability on excessive ROS [5,6].

Natural antioxidants contain a variety of molecules such as polyphenols [7], carotenoids [8], vitamins [9], nitrogen-containing compounds [10], and coumarins [9]. Polyphenols are distributed widely throughout the plant kingdom and promote health benefits owing to their 
antioxidant properties [11]. Many of them, such as resveratrol and some derivatives [12], anthocyanidins [13], isoflavones [14], catechin [15], and quercetin [16] are well known for their protective effect by scavenging ROS [1]. For the past few years, polyphenols have been attracting attention in the prevention of cancer [17], cardiovascular dysfunction [18], neurodegenerative diseases [19], and aging [20]. Therefore, searching for effective antioxidants is an urgent need to promote human health.

Anneslea fragrans Wall. is an evergreen plant, which is mainly distributed in the southern of China [21]. In addition to its ornamental purpose, the leaves of $A$. fragrans are also used as a folk medicine to treat fever, liver protection, invigorating stomach and intestines in China and Cambodia [22], which had been recorded in "Yunnan Simao Chinese Herbal Medicine". In addition, the leaves have also been processed as a tea beverage, which is known as "Pangpo Tea". In previous reports [23], the extract of A. fragrans has shown antioxidant and antimalarial activities. However, to date, its antioxidant phenolic compounds from $A$. fragrans have not been reported.

Thus, the purpose of this research was to isolate and identify the antioxidant compounds from $A$. fragrans leaves that are responsible for its traditional use for the treatment of liver diseases. The four fractions, dichloromethane fraction (DF), ethyl acetate fraction (EAF), $n$-butanol fraction (BF), and residual water fraction (RWF) of aqueous ethanol extract were assessed for their total phenolic (TPC) and total flavonoid contents (TFC) and for their antioxidant capacity. The $n$-butanol fraction (BF) had the highest TPC and TFC with strongest antioxidant activity. The bio-guided fractionation of BF allowed the purification of compounds. Furthermore, the cytoprotective effect of the isolated compounds was performed on hydrogen peroxide $\left(\mathrm{H}_{2} \mathrm{O}_{2}\right)$-induced oxidative stress in human liver cancer HepG2 cells. The intracellular ROS production and cell apoptosis were determined using flow cytometry. Thus, this research afforded a valuable antioxidant phytochemical ingredient for the development and utilization of $A$. fragrans leaves as a functional supplement (healthy tea) in food and health industry.

\section{Results and Discussion}

\subsection{Yield Efficiency of Fractions and Subfractions}

The liquid-liquid partitioning by organic solvents and column fractionation are important techniques for enriching the bioactive compounds from crude extract [24]. Using liquid-liquid partitioning, ethanol extract (CE) from $A$. fragrans leaves was successively fractionated with dichloromethane, ethyl acetate, and $n$-butanol to give four fractions (DF, EAF, BF, and RWF), respectively. Yield percentages of fractions were found to vary from 11 to $27 \%$. The residual water fraction (RWF, $27 \%$ ) had the highest yield, and the yields of other fractions were in the order as follows: $n$-butanol fraction (BF, 24\%), ethyl acetate fraction (EAF, 21\%), dichloromethane fraction (DF, 11\%).

The yield percentage of subfractions (BF-A to E) was found to vary from 3.82 to $48.4 \%$. The BF-E presented the highest yield of $48.4 \%$ followed by BF-D $(24.96 \%)$, which has significantly higher yields than the other fractions.

\subsection{HPLC Analysis}

High-performance liquid chromatography (HPLC) detection has been demonstrated to be a powerful technique for quantitative determination. HPLC analysis revealed that BF had the most compounds with the strongest antioxidant activity. Under the guidance of antioxidant assays and HPLC analysis, the antioxidative fraction was further chromatographed for the isolation of subfractions. The BF was subjected to a hydrated resin D101 column to yield five subfractions (BF-A to E). HPLC analysis revealed that BF-C to E had the most antioxidant compounds. Bio-guided fractionation of these fractions (BF-C to E) allowed the purification of seven pure compounds.

As shown in Figure 1, the BF and seven pure compounds were profiled by HPLC analysis. Based on comparison with the retention times and UV absorption curves, these seven compounds were confirmed through retention times at $7.51 \mathrm{~min}$ (cornoside, 7), $7.92 \mathrm{~min}$ ((epi)- 
catechin, 6), $9.38 \mathrm{~min}$ (confusoside, 1), $9.57 \mathrm{~min}$ ((S)-naringenin-7-O- $\beta$-D-glucopyranoside, 4), $10.32 \mathrm{~min}$ (vacciniifolin, 2), $12.64 \mathrm{~min}\left(2^{\prime}, 3,4,4^{\prime}\right.$-tetrahydroxydihydrochalcone, 5), and $13.95 \mathrm{~min}$ (1-[4-( $\beta$-D-glucopyranosyloxy)-2-hydroxyphenyl]-3-(4-hydroxy-3-methoxyphenyl)-1propanone, 3) (Figure 1A). Among them, compounds 1-6 belong to flavonoids, and compound 7 is benzoquinolethanoid.

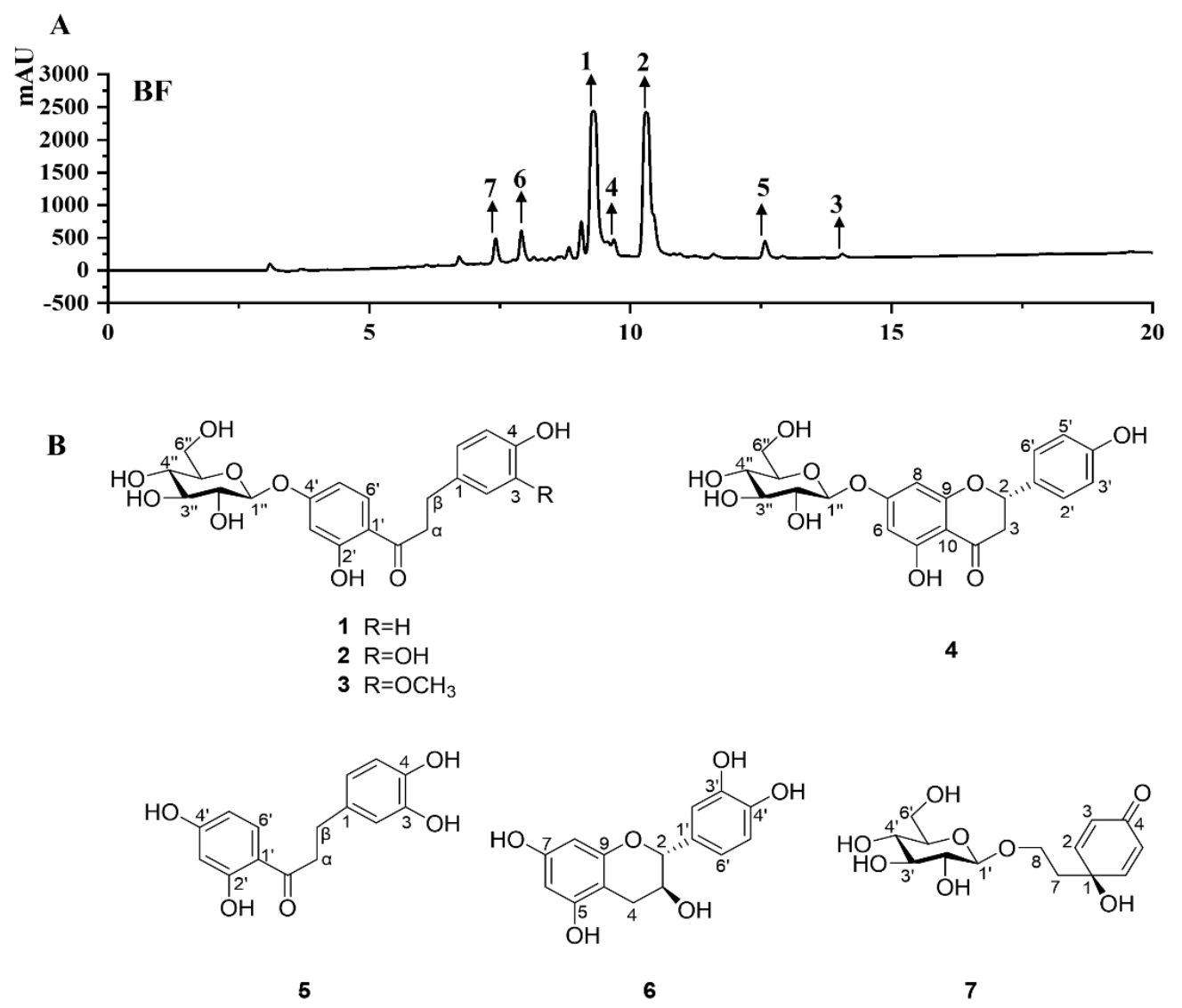

Figure 1. (A). HPLC chromatogram of BF from Anneslea fragrans. (B). Chemical structures of the compounds 1-7.

\subsection{Total Phenolic Contents (TPC) and Total Flavonoid Contents (TFC)}

The $A$. fragrans leaves are traditionally used as processed health tea and have been proven to be good resource of phenolics and flavonoids [25]. According to spectrophotometric assays, the TPC and TFC were tested in different fractions and subfractions from $A$. fragrans leaves. As shown in Table 1, the BF had the highest TPC value with $238.12 \pm 12.05 \mathrm{mg}$ GAE/g extract followed by EAF. The DF showed the lowest TPC value as $66.52 \pm 0.57 \mathrm{mg}$ GAE/g extract. Similarly, the highest TFC concentrations were also found in BF with TFC value as $165.19 \pm 5.21 \mathrm{mg} \mathrm{RE} / \mathrm{g}$ extract. With regard to the RWF and EAF (66.92 \pm 1.38 and $116.12 \pm 2.89 \mathrm{mg} \mathrm{GAE} / \mathrm{g}$ extract, respectively), they also had lower TFC concentrations than the BF (165.19 $\pm 5.21 \mathrm{mg}$ RE/g extract), while DF had the lowest TFC concentration as $47.94 \pm 2.84 \mathrm{mg} \mathrm{RE} / \mathrm{g}$ extract. The contents of TPC and TFC in BF were approximately four times higher than those in DF. 
Table 1. TPC, TFC, and antioxidant capacity values of four fractions and five subfractions from Anneslea fragrans Wall ${ }^{1}$.

\begin{tabular}{|c|c|c|c|c|c|}
\hline Samples & TPC & TFC & FRAP ${ }^{2}$ & ABTS $^{3}$ & $\mathrm{DPPH}^{4}$ \\
\hline $\mathrm{Vc}^{5}$ & - & - & $3126.08 \pm 197.63^{h}$ & $2932.91 \pm 93.63 \mathrm{~g}$ & $1873.56 \pm 121.68^{a}$ \\
\hline $\mathrm{DF}$ & $66.52 \pm 0.57^{b}$ & $47.94 \pm 2.84^{b}$ & $180.05 \pm 9.46^{\mathrm{b}}$ & $139.23 \pm 8.62^{\mathrm{a}}$ & $779.94 \pm 84.76^{b}$ \\
\hline EAF & $123.49 \pm 1.14^{\mathrm{d}}$ & $116.12 \pm 2.89^{d}$ & $975.24 \pm 16.73^{\mathrm{e}}$ & $796.92 \pm 19.26^{c}$ & $684.31 \pm 31.26^{b}$ \\
\hline $\mathrm{BF}$ & $238.12 \pm 12.05 \mathrm{~g}$ & $165.19 \pm 5.21^{\mathrm{f}}$ & $1822.96 \pm 29.24^{\mathrm{f}}$ & $1808.46 \pm 96.52^{d}$ & $951.42 \pm 87.75^{b}$ \\
\hline RWF & $81.29 \pm 1.48^{c}$ & $66.92 \pm 1.38^{c}$ & $592.65 \pm 11.55^{\mathrm{d}}$ & $135.38 \pm 6.75^{\mathrm{a}}$ & $613.38 \pm 45.35^{b}$ \\
\hline BF-A & $22.22 \pm 1.63^{a}$ & $25.46 \pm 2.89^{a}$ & $71.27 \pm 5.42^{\mathrm{a}}$ & $130.01 \pm 4.16^{\mathrm{a}}$ & $128.60 \pm 6.31^{\mathrm{a}}$ \\
\hline BF-B & $76.37 \pm 0.94^{\mathrm{c}}$ & $63.63 \pm 3.82^{c}$ & $427.61 \pm 13.78^{c}$ & $246.92 \pm 7.03^{b}$ & $615.31 \pm 38.21^{b}$ \\
\hline BF-C & $210.69 \pm 6.31^{\mathrm{e}}$ & $151.01 \pm 4.33^{\mathrm{e}}$ & $1777.94 \pm 72.93^{f}$ & $2020.87 \pm 97.29^{e}$ & $1249.87 \pm 81.59^{\mathrm{c}}$ \\
\hline BF-D & $219.84 \pm 4.01^{\mathrm{f}}$ & $157.01 \pm 2.50^{\mathrm{e}}$ & $1839.38 \pm 12.87^{f}$ & $1881.53 \pm 28.57^{d}$ & $1431.35 \pm 98.32 \mathrm{~cd}$ \\
\hline BF-E & $262.03 \pm 1.72^{h}$ & $180.52 \pm 6.30 \mathrm{~g}$ & $2096.77 \pm 49.13 \mathrm{~g}$ & $2162.31 \pm 64.49^{f}$ & $1660.42 \pm 119.72 \mathrm{de}$ \\
\hline
\end{tabular}

${ }^{1}$ TPC: total phenolic content expressed as mg GAE/g extract, TFC: total flavonoid content expressed as mg RE/g extract. All the values are expressed as mean $\pm \mathrm{SD}(n=3)$. Data are obtained from three replicates and presented as mean $\pm \mathrm{SD}$; different numbers in the same column with different letters as superscript are significantly different $(p<0.05)$. DF, EAF, BF, and RWF mean dichloromethane fraction, ethyl acetate fraction, $n$-butanol fraction, and residual water fraction. BF-A to E mean that BF was subjected to D101 column chromatography to yield five subfractions. ${ }^{2}$ FRAP: $\mu \mathrm{mol}$ Trolox equivalents (TE)/g extract. ${ }^{3}$ ABTS: $\mu$ mol Trolox equivalents (TE)/g extract. ${ }^{4}$ DPPH: $\mu$ mol Trolox equivalents (TE)/g extract. ${ }^{5}$ Vc means the standard of vitamin C.

The data depicted the presence of highest TPC and TFC in BF-E with values as $262.03 \pm 1.72 \mathrm{mg} \mathrm{GAE} / \mathrm{g}$ extract; $180.52 \pm 6.30 \mathrm{mg}$ RE/g extract, respectively, followed by $\mathrm{BF}-\mathrm{D}(219.84 \pm 4.01$ and $157.01 \pm 2.50 \mathrm{mg} \mathrm{RE} / \mathrm{g}$ extract, respectively), BF-C (210.69 \pm 6.31 and $151.01 \pm 4.33 \mathrm{mg} \mathrm{RE} / \mathrm{g}$ extract, respectively), while BF-B and BF-A had the lowest TPC and TFC values (Table 1).

\subsection{Antioxidant Activity}

Most of the polyphenols, especially flavonoids and phenolic acids, are exploited into popular antioxidant foods (nutraceuticals) and present a series of human benefits [17]. In our previous study, the $A$. fragrans leaves have been proven to be a good resource of polyphenols [26]. However, the antioxidant activity of the extract from $A$. fragrans leaves and its phytochemicals have not been investigated yet. Due to different antioxidative reaction mechanisms, three assays of ABTS, DPPH, and FRAP were combined to evaluate the antioxidant activity of the fractions and subfractions from $A$. fragrans leaves.

Among the fractions, BF showed the most potent antioxidant activity in ABTS, $\mathrm{DPPH}$, and FRAP radical-scavenging activities with $1808.46 \pm 96.52,951.42 \pm 87.75$, and $1822.96 \pm 29.24 \mu \mathrm{mol}$ TE/g extract (Table 1 ). DF showed the lowest antioxidative activity in ABTS and FRAP assays (139.23 $\pm 8.62 \mu \mathrm{mol} \mathrm{TE} / \mathrm{g}$ extract and $180.05 \pm 9.46 \mu \mathrm{mol} \mathrm{TE} / \mathrm{g}$ extract, respectively) (Table 1 ). Whereas, the radical scavenging activities of four fractions (DF, EAF, BF, and RWF) in the DPPH radical-scavenging assay were found to vary from $613.38 \pm 45.35$ to $951.42 \pm 87.75 \mu \mathrm{mol} \mathrm{TE} / \mathrm{g}$ extract, respectively, having no significant difference $(p>0.05)$. These results suggested that the phytochemicals from $A$. fragrans leaves might be insensitive to DPPH. To further obtain the active metabolites, BF was selected for further fractionation. The BF was subjected to D101 macroporous adsorbing resin column chromatography eluting by a gradient of the methanol-aqueous system to yield five subfractions (BF-A to E). Hence, the ABTS radical-scavenging activity of these subfractions can be ranked as BF-E $>$ BF-C $>$ BF-D. The reducing activity in the FRAP assay revealed that $\mathrm{BF}-\mathrm{D}$ had the strongest antioxidative activity, which was followed by $\mathrm{BF}-\mathrm{C}$ and BF-E. It is noteworthy that three subfractions (BF-C to E) presented higher antioxidative activity than the mother fraction (BF). Taken together, BF-C to E were submitted to column chromatography for isolating and identifying the antioxidative phytochemicals.

\subsection{Antioxidant Activity of the Isolated Compounds}

All the isolated compounds (compounds 1-7) were evaluated for antioxidant capacity by ABTS, DPPH radical scavenging activity, and FRAP antioxidant activity. All the data are described in Table 2. Compounds $\mathbf{6}$ and $\mathbf{2}$ showed the highest antioxidant activity, 
followed by 5 . Compound 4 displayed moderate antioxidant activity and compounds 1,3 , and 7 were considered inactive with ABTS and DPPH radical scavenging activities less than $200 \mu \mathrm{mol} \mathrm{TE} / \mathrm{g}$ extract. Using Vc (the radical scavenging activities with $2932.91 \pm 93.63$ and $1873.56 \pm 121.68 \mu \mathrm{mol} \mathrm{TE} / \mathrm{g}$ extract, respectively) as the positive control, compound 6 had the strongest antioxidant activity in ABTS and DPPH radical scavenging assays with $1580.37 \pm 89.32$ and $1953.31 \pm 109.93 \mu \mathrm{mol} \mathrm{TE} / \mathrm{g}$ extract $(p<0.05)$, respectively. Furthermore, compound 6 had the best antioxidant capacity in the FRAP assay as $5027.43 \pm 620.75 \mu \mathrm{mol} \mathrm{TE} / \mathrm{g}$ extract, which was much higher than that of $\mathrm{Vc}$ as $3291.28 \pm 241.02 \mu \mathrm{mol}$ TE/g extract. Moreover, compounds $\mathbf{2}$ and $\mathbf{6}$ showed a significant antioxidant activity, which was equivalent to positive control (Vc).

Table 2. Antioxidant capacity values of seven compounds from Anneslea fragrans Wall ${ }^{1}$.

\begin{tabular}{cccc}
\hline Compound & FRAP $^{2}$ & ABTS $^{3}$ & DPPH $^{\mathbf{4}}$ \\
\hline $\mathrm{Vc}^{5}$ & $3126.08 \pm 197.63^{\mathrm{e}}$ & $2932.91 \pm 93.63^{\mathrm{e}}$ & $1873.56 \pm 121.68^{\mathrm{c}}$ \\
$\mathbf{1}$ & $714.17 \pm 64.63^{\mathrm{b}}$ & $174.81 \pm 14.38^{\mathrm{a}}$ & $133.33 \pm 4.98^{\mathrm{a}}$ \\
$\mathbf{2}$ & $3065.37 \pm 283.87^{\mathrm{e}}$ & $1312.41 \pm 108.63^{\mathrm{c}}$ & $1888.31 \pm 162.94^{\mathrm{c}}$ \\
$\mathbf{3}$ & $562.09 \pm 63.98^{\mathrm{a}}$ & $126.37 \pm 9.32^{\mathrm{a}}$ & $128.33 \pm 9.93^{\mathrm{a}}$ \\
$\mathbf{4}$ & $2806.15 \pm 171.92^{\mathrm{d}}$ & $1021.92 \pm 51.82^{\mathrm{b}}$ & $1418.31 \pm 84.62^{\mathrm{b}}$ \\
$\mathbf{5}$ & $2448.36 \pm 150.38^{\mathrm{c}}$ & $1132.16 \pm 93.85^{\mathrm{b}}$ & $1533.31 \pm 114.96^{\mathrm{b}}$ \\
$\mathbf{6}$ & $5027.43 \pm 620.75^{\mathrm{f}}$ & $1580.37 \pm 89.32^{\mathrm{d}}$ & $1953.31 \pm 109.93^{\mathrm{c}}$ \\
$\mathbf{7}$ & $613.94 \pm 87.29^{\mathrm{a}}$ & $54.18 \pm 4.38^{\mathrm{a}}$ & $108.33 \pm 8.71^{\mathrm{a}}$ \\
\hline
\end{tabular}

${ }_{1}^{1}$ TPC: total phenolic content expressed as mg GAE/g extract, TFC: total flavonoid content expressed as mg RE/g extract. Data are obtained from three replicates and presented as mean $\pm \mathrm{SD}$; different numbers in the same column with different letters as superscript are significantly different $(p<0.05) .{ }^{2}$ FRAP: $\mu$ mol Trolox equivalents (TE)/g extract. ${ }^{3}$ ABTS: $\mu$ mol Trolox equivalents (TE)/g extract. ${ }^{4}$ DPPH: $\mu \mathrm{mol}$ Trolox equivalents (TE)/g extract. ${ }^{5} \mathrm{Vc}$ means the standard of vitamin $\mathrm{C}$.

Additionally, the antioxidant structure-activity relationship of the flavonoids (1-6) is discussed by varying degrees of inhibitory effects. Compound 2 presented more antioxidant activity than compounds 1,3, and 5, which suggested that the 3,4-dihydroxy groups in dihydrochalcones in 2 may play a critical role against ABTS, DPPH radical scavenging activity, and FRAP antioxidant activity, and the glucose moiety substituted at C- $4^{\prime}$ in 2 may play an important role on its antioxidant capacity [4]. Furthermore, compound 6 exhibited the highest antioxidant activity compared to other compounds, which suggested that flavan-3-ols (catechin) probably exhibit a better radical scavenging activity than dihydrochalcones and flavanones [27]. In summary, compounds 2, 5, and $\mathbf{6}$ with good antioxidant activity were selected further for cytoprotective effects against oxidative stress by $\mathrm{H}_{2} \mathrm{O}_{2}$ in the next study.

\subsection{Relationship between Antioxidant Activity and TPC/TFC Contents}

Concentrations of the TPC and TFC highly correlated with antioxidant activity from the values of FRAP $(r=0.982$ and 0.977$)$ and ABTS $(r=0.959$ and 0.965$)$, respectively. The correlation matrix also showed strong correlation between the ABTS and FRAP values $(\mathrm{r}=0.992)$. Furthermore, a multivariate analysis (PCA), which was extracted from the data of Table 1, was carried out. As shown in Figure 2, PCA explained 94.44\% of total variation, in which PC1 accounted for $84.73 \%$ of the variance and PC2 accounted for $9.71 \%$. The FRAP, ABTS, and DPPH assays with EAF and RWF are placed at the upper right quadrants, and TPC and TFC concentrations with BF and BF-C to $E$ are located at the lower right quadrants in the PC1 positive scores, respectively. Meanwhile, the DF and BF-A to B with low TPC and TFC concentrations are located along the axis of PC1 negative scores. These findings showed that the TPC and/or TFC concentrations are closely associated with antioxidant capacity, and the greater the TPC or TFC concentrations in the fractions and subfractions, the higher their antioxidant capacity values. These results revealed that the high phenolic and flavonoid contents in different fractions and subfractions from $A$. fragrans leaves might contribute to antioxidant activity. 
Biplot（PC1×PC2: $94.44 \%)$

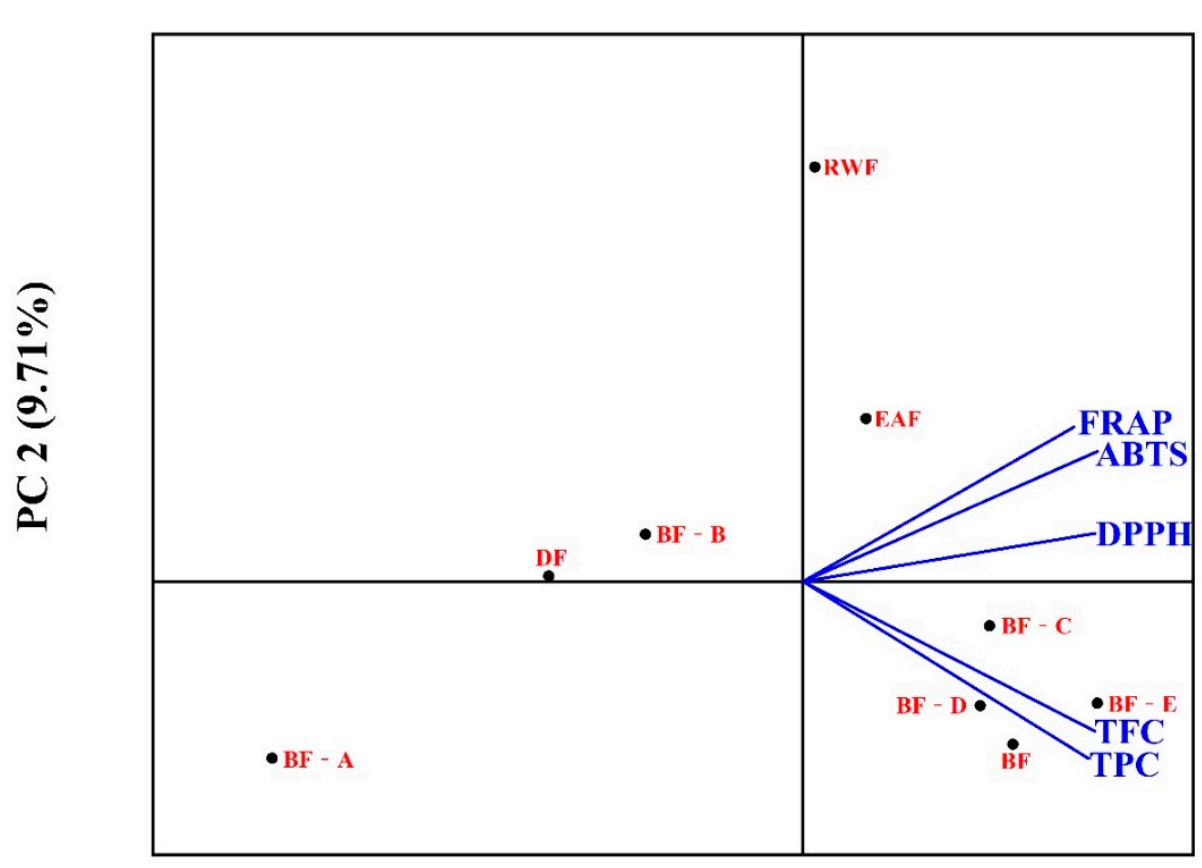

PC 1 (84.73\%)

Figure 2. PCA analysis on total phenolics, flavonoids, and antioxidant activity. Means with different letters indicate significant differences $(p<0.05)$. DF, EAF, BF, RWF mean dichloromethane fraction, ethyl acetate fraction, $n$-butanol fraction, and residual water fraction. BF-A to E means BF was subjected to D101 column chromatography to yield five subfractions.

\subsection{Inhibitory Effect on Intracellular ROS Generation}

Oxidative stress is a kind of imbalance between oxidation and antioxidation in the body [28]. Excessive accumulation of ROS can lead to oxidative stress that may cause damage to cells and tissues such as lipids, membranes, and DNA [29]. Antioxidants including polyphenols and flavonoids can help the body reduce these damages caused by ROS. Generally, $\mathrm{H}_{2} \mathrm{O}_{2}$ is widely used to induce intracellular ROS disordered production and impair the antioxidant defense of cells [30]. In our present study, $\mathrm{H}_{2} \mathrm{O}_{2}$ was chosen to induce the abnormal accumulation of intracellular ROS and impair the antioxidant defense of cells. To evaluate the inhibitory effect on intracellular ROS generation in $\mathrm{H}_{2} \mathrm{O}_{2}$-induced HepG2 cells, the levels of intracellular ROS were tested by flow cytometry. Briefly, HepG2 cells were cultured in a 6 -well plate $\left(1 \times 10^{5}\right.$ cells/well). After incubation for $24 \mathrm{~h}$ of $50 \mu \mathrm{g} / \mathrm{mL}$ of different extracts or $8 \mu \mathrm{g} / \mathrm{mL}$ of $\mathrm{V}_{\mathrm{c}}$ (positive group), all the groups except for the control group were induced by $\mathrm{H}_{2} \mathrm{O}_{2}$ for $6 \mathrm{~h}$. The intracellular ROS levels of each compound were tested (Figure 3). The ROS generation ratio significantly increased to $215.64 \pm 9.80 \%$ in $\mathrm{H}_{2} \mathrm{O}_{2}$-treated group compared with the control group (100\%). Compared with the $\mathrm{H}_{2} \mathrm{O}_{2}$-treated group, compounds 2, 5, and 6 remarkably suppressed intracellular ROS production $(p<0.05)$, and their inhibitory effect was equal to the Vc group (Figure 3 ). Many phenolics have been proven to have protective effect against intracellular ROS by $\mathrm{H}_{2} \mathrm{O}_{2}$ induction [31]. Additionally, compound 6 displayed the strongest suppressive effect on intracellular ROS production, which suggests that flavonoid compounds play a crucial role in inhibiting intracellular ROS production. 
A

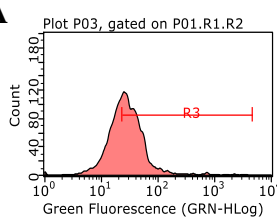

Control

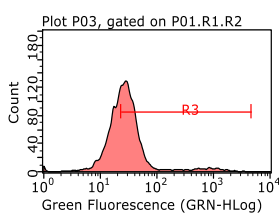

Compound 2

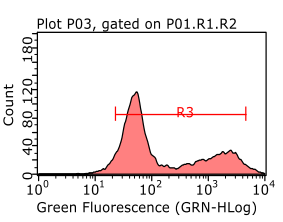

$\mathrm{H}_{2} \mathrm{O}_{2}$

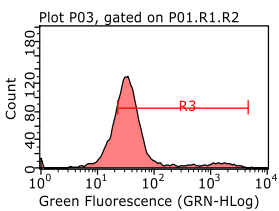

Compound 5

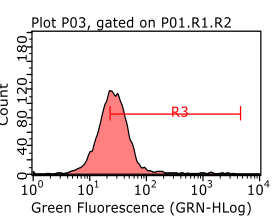

$\mathrm{Vc}$

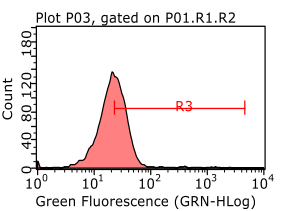

Compound 6
B

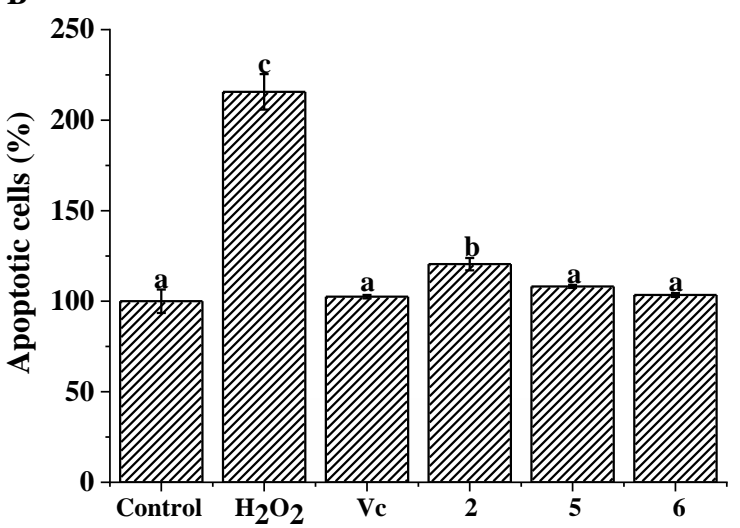

Figure 3. The inhibitory effects of compounds 2, 5, and $\mathbf{6}$ on intracellular ROS in $\mathrm{H}_{2} \mathrm{O}_{2}$-induced HepG2 cells. (A) Flow cytometry analysis; (B) the ROS intensity of different groups. All the values are presented as mean \pm SD $(n=3)$. Means (bar values) with different letters indicate significant differences $(p<0.05)$.

\subsection{Cytoprotective Effect Against $\mathrm{H}_{2} \mathrm{O}_{2}$-Induced Cell Apoptosis}

Apoptosis is a basic biological phenomenon of cells, which plays an important role in the regulatory mechanism of cells' proliferation, growth, and mutation, and the stability of the internal environment. Apoptosis, different from necrosis, is a special type of cell death. The disorder of apoptotic process has bad effects on the body and causes many diseases [32] $\mathrm{H}_{2} \mathrm{O}_{2}$, as an important signaling molecule, regulates the process of cell proliferation, growth, and apoptosis [5]. The present study measured the apoptosis of $\mathrm{H}_{2} \mathrm{O}_{2}$-induced HepG2 cells and evaluated the cytoprotective effects of compounds 2, 5, and 6. After treating HepG2 cells with $1.0 \mathrm{mM} \mathrm{H}_{2} \mathrm{O}_{2}$, the apoptosis ratio remarkably augmented $(57.20 \pm 1.97 \%)$, compared with that of the control group $(9.10 \pm 0.62 \%, p<0.05)$ (Figure 4). The ratios of apoptotic cells in the treated groups of compounds 2, 5, and 6 significantly decreased compared with the $\mathrm{H}_{2} \mathrm{O}_{2}$-treated group (model group, $p<0.05$ ) (Figure 4). Moreover, compound 6 had significantly efficiency on protecting HepG-2 cells from $\mathrm{H}_{2} \mathrm{O}_{2}$ toxicity, and the cell apoptosis ratio of $6(10.56 \pm 1.15 \%)$ was lower than that of the $\mathrm{V}_{c}$ group (positive control), which was equal to that of the control group (Figure 4). Meanwhile, compounds $\mathbf{2}$ and $\mathbf{5}$ showed moderate cytoprotective effect with cell apoptosis ratios of $2(26.76 \pm 2.60 \%)$ and $5(27.64 \pm 0.83 \%)$. The differences of antioxidant capacity may be attributed to the number of phenolic hydroxyl moieties and the link positions.

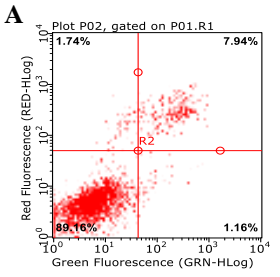

Control

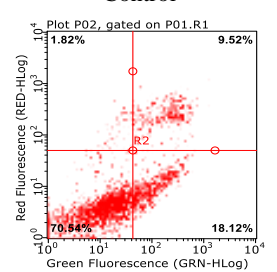

Compound 2

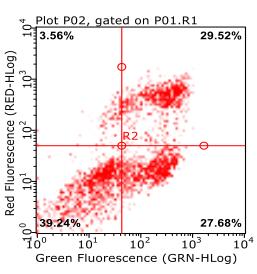

$\mathrm{H}_{2} \mathrm{O}_{2}$

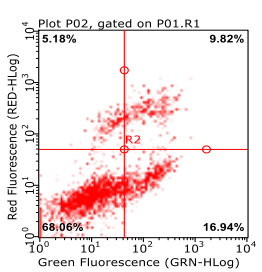

Compound 5

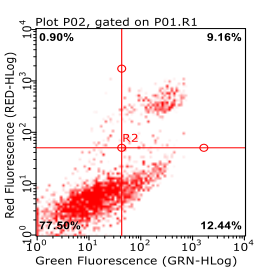

$\mathrm{Vc}$

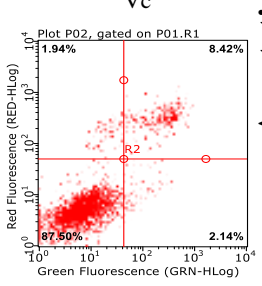

Compound 6

B

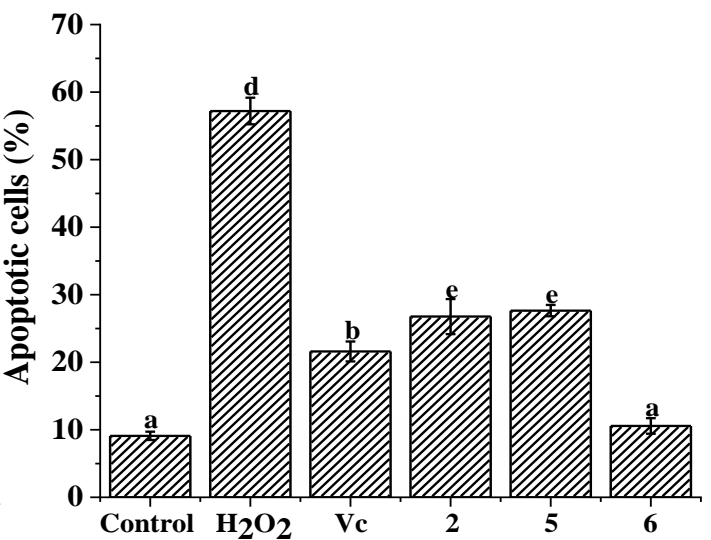

Figure 4. Cytoprotective effect of the compounds 2, 5, and $\mathbf{6}$ on apoptosis in $\mathrm{H}_{2} \mathrm{O}_{2}$-induced HepG-2 cells. (A) Flow cytometry analysis; (B) the apoptotic cell percentage of different groups. All the values are presented as mean $\pm \mathrm{SD}(n=3)$. Means (bar value) with different letters are significantly different $(p<0.05)$. 


\section{Materials and Methods}

\subsection{Chemicals and Reagents}

Methanol, acetonitrile, and formic acid for high-performance liquid chromatography (HPLC) were of HPLC grade and purchased from Merck (Darmstadt, Germany). Solvents for sample extraction including ethanol, dichloromethane, and $n$-butanol were of analytical grade. Deionized water was purified using a Milli-Q ultrapure water system (Millipore, Bedford, Massachusetts, MA, USA) and employed in all the experiments. Phenolic standard compounds of gallic acid, rutin, Trolox, and vitamin $C$ were purchased from Chengdu Must Bio-Technology Co., Ltd. (Chengdu, China). Methylthiazol-2-yl-2,5-diphenyl tetrazolium bromide (MTT), Folin-Ciocalteu reagent, 2,2'-azino-bis(3-ethylbenzo-thiazoline-6sulfonic acid) (ABTS), 2,2-diphenyl-1-picrylhydrazyl radical (DPPH), 1,3,5-tri(2-pyridyl)2,4,6-triazine (TPTZ), $2^{\prime}, 7^{\prime}$-dichlorofluorescin diacetate (DCFH-DA), and $\mathrm{FeSO}_{4} \cdot 7 \mathrm{H}_{2} \mathrm{O}$ were purchased from Sigma-Aldrich (Shanghai, China). The NMR spectra were obtained using Bruker AV-400, and/or DRX-500 spectrometers. ESIMS spectra were recorded on An Agilent 1290 UPLC/6540 Q-TOF spectrometer.

\subsection{Sample Preparation}

Anneslea fragrans Wall. leaves were collected from the Lincang city of China in July 2020. The leaves were dried in a shade room until constant weight and then were powdered with an electric grinder. The extraction and fractionation were performed as our previously reported method with slight modification [33]. The powdered sample (100 g) was mixed with $1000 \mathrm{~mL}$ of $80 \%$ aqueous ethanol solvent and ultrasonicated in an ultrasonic cleaning bath at $200 \mathrm{~W}$ for three times $(0.5 \mathrm{~h}$ per time). Then, the sonicated slurry was collected and centrifuged at $1500 \times g$ for $10 \mathrm{~min}$ by Eppendorf centrifuge (TGL-20B, Shanghai Anting Scientific Instrument Factory, Shanghai, China). The combined supernatant was concentrated at $50^{\circ} \mathrm{C}$ by a rotary evaporator (Hei-VAP, Heidolph, Germany) and further dried by a vacuum drying lyophilizer (Alpha 1-2 LD plus, Christ, Germany). The crude ethanol extract $(\mathrm{CE}, 30 \mathrm{~g})$ was re-suspended with water and sequentially partitioned with dichloromethane, ethyl acetate, and $n$-butanol solvents three times. After concentration and lyophilization, the dichloromethane fraction (DF), ethyl acetate fraction (EAF), $n$-butanol fraction (BF), and residual water fraction (RWF) weighing $3.2 \mathrm{~g}, 6.3 \mathrm{~g}, 7.2 \mathrm{~g}$, and $8.2 \mathrm{~g}$ were obtained, respectively. According to the antioxidant activities of different fractions, the BF was chromatographed on glass columns $(30 \mathrm{~mm} \times 400 \mathrm{~mm}$ ) wet-packed with $20 \mathrm{~g}$ (dry resin) of the selected hydrated resin D101. The bed volume (BV) of the resin was about $40 \mathrm{~mL}$. After reaching the adsorptive saturation, the column was first washed by distilled water with $4 \times \mathrm{BV}$ and then eluted by ethanol-water $(0: 100,20: 80,50: 50,80: 20,100: 0, v / v$, each $4 \times \mathrm{BV}$ ), to yield five subfractions (BF-A to E). Each part of the desorption solutions was concentrated to dryness under vacuum. The $\mathrm{CE}$, four fractions $(\mathrm{DF}, \mathrm{EAF}, \mathrm{BF}$, and RWF) and five subfractions (BF-A to E) were stored in a refrigerator $\left(-20^{\circ} \mathrm{C}\right)$ for further experimentation.

\subsection{Bio-Guided Isolation of Active Constituents}

Under the guidance of antioxidant assays and HPLC analysis, the antioxidative fraction was further chromatographed for the isolation of pure compounds. In brief, the BF was subjected to a hydrated resin D101 column to yield five subfractions (BF-A to E). The BF-C (1.5 g) was subjected to a silica gel column, eluting with $\mathrm{DCM} / \mathrm{MeOH}(15: 1)$, and then was separated using preparative TLC (DCM/MeOH, 10:1) to obtain compounds 6 $(118 \mathrm{mg})$ and $7(10 \mathrm{mg})$. BF-D $(1.1 \mathrm{~g})$ was subjected to silica gel column $\left(\mathrm{CHCl}_{3} / \mathrm{MeOH}\right.$ 10:1, 5:1) to give compounds $1(129 \mathrm{mg})$ and $4(15 \mathrm{mg})$. BF-E (1.2 g) was subjected to silica gel column $\left(\mathrm{CHCl}_{3} / \mathrm{MeOH}, 30: 1,10: 1,5: 1\right)$ to yield compounds 1 (216 mg), 2 (135 mg), and a mixture. The later was purified by silica gel column $\left(\mathrm{CHCl}_{3} / \mathrm{MeOH}, 12: 1\right)$ to afford compounds 3 (19 $\mathrm{mg}$ ) and $\mathbf{5}$ (15 mg) (Figure 5). 


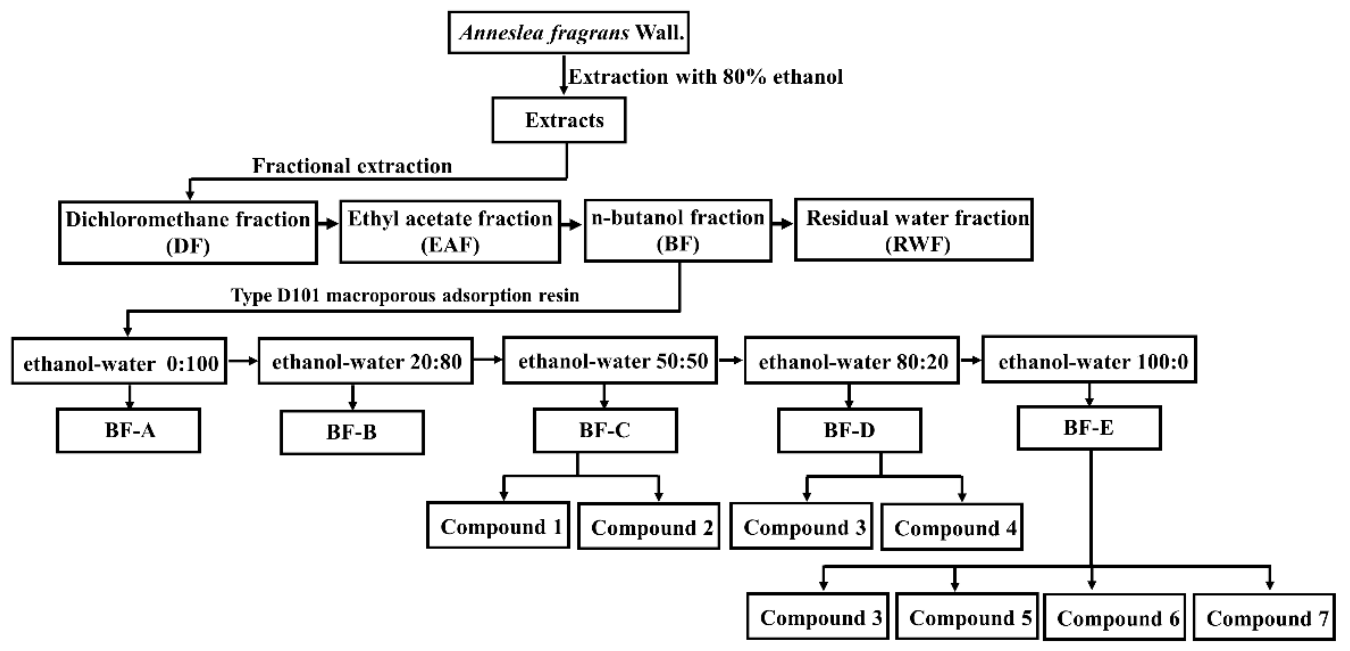

Figure 5. Extraction and isolation procedure of the compounds from $80 \%$ aqueous ethanol extract from Anneslea fragrans leaves.

\subsection{Structure Elucidation of Compounds $\mathbf{1}-\mathbf{7}$}

According to the antioxidant activities of different fractions, three subfractions, BF-C to $\mathrm{E}$ were submitted to column chromatography. In this way, the bioactivity-guided fractionation of BF-C to $\mathrm{E}$ led to the isolation of seven individual phenolic compounds. Their structures were identified as confusoside (1) [34], vacciniifolin (2) [34], 1-[4-( $\beta$-D-glucopyranosyloxy)-2hydroxyphenyl]-3-(4-hydroxy-3-methoxyphenyl)-1-propanone (3) [35], (S)-naringenin-7-O- $\beta$ D-glucopyranoside (4) [22], 2' ,3,4,4'-tetrahydroxydihydrochalcone (5) [26], (epi)-catechin (6) [26], and cornoside (7) [36] (Figure 1B) by the analysis of 1D-NMR and ESI-MS data and comparison with the previously reported compounds in the literature. Among them, compounds 3, 4, and 7 were isolated from this plant for the first time.

Confusoside (1). The molecular formula was assigned as $\mathrm{C}_{21} \mathrm{H}_{24} \mathrm{O}_{9}$, and the separation gave $129 \mathrm{mg}$ of pale-yellow needles. ${ }^{1} \mathrm{H}$ NMR $\left(500 \mathrm{MHz}\right.$, DMSO- $\left.d_{6}\right)$ and ESI-MS $(m / z 421$ $[\mathrm{M}+\mathrm{H}]^{+}$) data were identical to the previously reported compound in the literature [34]. The identification was further supported by ${ }^{13} \mathrm{C}$ NMR (125 MHz, DMSO- $\left.d_{6}\right): \delta 204.4$ (s, $\mathrm{C}=\mathrm{O}), 163.5\left(\mathrm{~s}, \mathrm{C}-2^{\prime}\right), 163.3\left(\mathrm{~s}, \mathrm{C}-4^{\prime}\right), 155.5(\mathrm{~s}, \mathrm{C}-4), 132.6\left(\mathrm{~d}, \mathrm{C}-6^{\prime}\right), 130.9$ (s, C-1), 129.2 (d, C-2, 6), $115.0(\mathrm{~d}, \mathrm{C}-3 / \mathrm{C}-5), 114.4\left(\mathrm{~s}, \mathrm{C}-\mathrm{1}^{\prime}\right), 108.3\left(\mathrm{~d}, \mathrm{C}-5^{\prime}\right), 103.4\left(\mathrm{~d}, \mathrm{C}-1^{\prime \prime}\right), 99.6\left(\mathrm{~d}, \mathrm{C}-3^{\prime}\right), 77.1(\mathrm{~d}$, C-5"), $76.4\left(\mathrm{~d}, \mathrm{C}-3^{\prime \prime}\right), 73.1\left(\mathrm{~d}, \mathrm{C}-2^{\prime \prime}\right), 69.5\left(\mathrm{~d}, \mathrm{C}-4^{\prime \prime}\right), 60.5\left(\mathrm{t}, \mathrm{C}-6^{\prime \prime}\right), 39.8(\mathrm{t}, \mathrm{C}-\alpha), 28.9(\mathrm{t}, \mathrm{C}-\beta)$.

Vacciniifolin (2) was obtained as yellow amorphous powder (153 mg) and assigned a molecular formula of $\mathrm{C}_{21} \mathrm{H}_{24} \mathrm{O}_{10} \cdot{ }^{1} \mathrm{H}$ NMR ( $500 \mathrm{MHz}$, DMSO- $\left.d_{6}\right)$ and ESI-MS $(m / z 437$ $\left.[\mathrm{M}+\mathrm{H}]^{+}\right)$data were the same as the previous reported data [34]. The identification was further supported by ${ }^{13} \mathrm{C}$ NMR (125 MHz, DMSO- $\left.d_{6}\right): \delta 204.4(\mathrm{~s}, \mathrm{C}=\mathrm{O}), 163.5\left(\mathrm{~s}, \mathrm{C}-2^{\prime}\right), 163.3$ (s, C-4' $), 145.0$ (s, C-3), 143.3 (s, C-4), 132.6 (d, C-6'), 131.7 (s, C-1), 118.9 (d, C-6), 115.8 (d, C-2), $115.4(\mathrm{~d}, \mathrm{C}-5), 114.4\left(\mathrm{~s}, \mathrm{C}-1^{\prime}\right), 108.3\left(\mathrm{~d}, \mathrm{C}-5^{\prime}\right), 103.4\left(\mathrm{~d}, \mathrm{C}-1^{\prime \prime}\right), 99.6\left(\mathrm{~d}, \mathrm{C}-3^{\prime}\right), 77.1(\mathrm{~d}$, C-5 $\left.5^{\prime \prime}\right), 76.4\left(\mathrm{~d}, \mathrm{C}-3^{\prime \prime}\right), 73.1\left(\mathrm{~d}, \mathrm{C}-2^{\prime \prime}\right), 69.5\left(\mathrm{~d}, \mathrm{C}-4^{\prime \prime}\right), 60.5\left(\mathrm{t}, \mathrm{C}-6^{\prime \prime}\right), 39.4(\mathrm{t}, \mathrm{C}-\alpha), 29.1(\mathrm{t}, \mathrm{C}-\beta)$.

1-[4-( $\beta$-D-Glucopyranosyloxy)-2-hydroxyphenyl]-3-(4-hydroxy-3-methoxyphenyl)-1propanone (3). The compound was obtained as colorless needles (19 $\mathrm{mg})$, and the molecular formula was assigned as $\mathrm{C}_{22} \mathrm{H}_{26} \mathrm{O}_{10} \cdot{ }^{1} \mathrm{H}$ NMR ( $400 \mathrm{MHz}$, DMSO- $\left.d_{6}\right)$ and ESI-MS $(m / z 451$ $\left.[\mathrm{M}+\mathrm{H}]^{+}\right)$data agreed with the literature [35]. The identification was further supported by ${ }^{13} \mathrm{C}$ NMR (100 MHz, DMSO- $\left.d_{6}\right): \delta 204.5$ (s, C=O), 163.5 (s, C-2'), $163.3\left(\mathrm{~s}, \mathrm{C}-4^{\prime}\right), 147.4$ (s, C-3), 144.6 (s, C-4), 132.6 (d, C-6'), 131.6 (s, C-1), 120.4 (d, C-6), 115.2 (d, C-5), 114.5 (s, C-1' $112.6(\mathrm{~d}, \mathrm{C}-2), 108.3\left(\mathrm{~d}, \mathrm{C}-5^{\prime}\right), 103.3\left(\mathrm{~d}, \mathrm{C}-1^{\prime \prime}\right), 99.5\left(\mathrm{~d}, \mathrm{C}-3^{\prime}\right), 77.0\left(\mathrm{~d}, \mathrm{C}-5^{\prime \prime}\right), 76.3\left(\mathrm{~d}, \mathrm{C}-3^{\prime \prime}\right)$, $73.0\left(\mathrm{~d}, \mathrm{C}-2^{\prime \prime}\right), 69.5\left(\mathrm{~d}, \mathrm{C}-4^{\prime \prime}\right), 60.5\left(\mathrm{t}, \mathrm{C}-6^{\prime \prime}\right), 55.5\left(\mathrm{q}, \mathrm{C}-\mathrm{OCH}_{3}\right), 39.5(\mathrm{t}, \mathrm{C}-\alpha), 29.4(\mathrm{t}, \mathrm{C}-\beta)$.

(S)-Naringenin-7-O- $\beta$-D-glucopyranoside (4) had the molecular formula of $\mathrm{C}_{21} \mathrm{H}_{22} \mathrm{O}_{10}$, which was obtained as $15 \mathrm{mg}$ of white powder. ${ }^{1} \mathrm{H}$ NMR ( $500 \mathrm{MHz}$, DMSO- $d_{6}$ ) and ESI-MS $\left(m / z 435[\mathrm{M}+\mathrm{H}]^{+}\right)$data were in agreement with the previous work [22]. The identification was further supported by ${ }^{13} \mathrm{C}$ NMR (125 MHz, DMSO- $\left.d_{6}\right): \delta 197.2$ (s, C-4), 165.3 (s, C-7), 
165.2 (s, C-5), 162.9 (s, C-9), $157.9\left(\mathrm{~s}, \mathrm{C}-4^{\prime}\right), 128.6\left(\mathrm{~s}, \mathrm{C}-1^{\prime}\right), 128.4\left(\mathrm{~d}, \mathrm{C}-2^{\prime}, 6^{\prime}\right), 115.2$ (d, C-3' $/$ C-5') 103.2 (s, C-10), $99.6\left(\mathrm{~d}, \mathrm{C}-1^{\prime \prime}\right), 96.5$ (d, C-6), $95.4(\mathrm{~d}, \mathrm{C}-8), 78.7$ (d, C-2), 77.0 (d, $\left.\mathrm{C}-5^{\prime \prime}\right), 76.3\left(\mathrm{~d}, \mathrm{C}-3^{\prime \prime}\right), 73.0\left(\mathrm{~d}, \mathrm{C}-2^{\prime \prime}\right), 69.5\left(\mathrm{~d}, \mathrm{C}-4^{\prime \prime}\right), 60.5\left(\mathrm{t}, \mathrm{C}-6^{\prime \prime}\right), 42.0(\mathrm{t}, \mathrm{C}-3)$.

$2^{\prime}, 3,4,4^{\prime}$-Tetrahydroxydihydrochalcone (5) possessed the molecular formula as $\mathrm{C}_{15} \mathrm{H}_{14} \mathrm{O}_{5}$ and separated $(15 \mathrm{mg})$ as white powder. ${ }^{1} \mathrm{H}$ NMR $\left(400 \mathrm{MHz}, \mathrm{DMSO}-d_{6}\right)$ and ESI-MS $\left(m / z 275[\mathrm{M}+\mathrm{H}]^{+}\right)$data were consistent with that reported in the literature [26]. The identification was further supported by ${ }^{13} \mathrm{C}$ NMR $\left(125 \mathrm{MHz}, \mathrm{DMSO}-d_{6}\right): \delta 203.9$ (s, C=O), 164.7 (s, C-2'), 164.2 (s, C-4'), 144.9 (s, C-3), 143.3 (s, C-4), 133.0 (d, C-6' ), 131.8 (s, C-1), 118.9 (d, C-6), $115.7(\mathrm{~d}, \mathrm{C}-2), 115.4(\mathrm{~d}, \mathrm{C}-5), 112.5\left(\mathrm{~s}, \mathrm{C}-1^{\prime}\right), 108.2\left(\mathrm{~d}, \mathrm{C}-5^{\prime}\right), 102.4\left(\mathrm{~d}, \mathrm{C}-3^{\prime}\right), 39.5(\mathrm{t}$, $\mathrm{C}-\alpha), 29.2(\mathrm{t}, \mathrm{C}-\beta)$.

(Epi)-catechin (6) was isolated as white powder (118 mg) and established the molecular formula as $\mathrm{C}_{11} \mathrm{H}_{6} \mathrm{O}_{4} \cdot{ }^{1} \mathrm{H}$ NMR $\left(400 \mathrm{MHz}, \mathrm{DMSO}-d_{6}\right)$ and ESI-MS $\left(m / z 291[\mathrm{M}+\mathrm{H}]^{+}\right)$ data agreed well with that reported in the literature [26]. The identification was further supported by ${ }^{13} \mathrm{C}$ NMR (125 MHz, DMSO- $\left.d_{6}\right)$ : $\delta 156.4$ (s, C-7), 156.1 (s, C-5), 155.3 (s, C-9), $144.8\left(\mathrm{~s}, \mathrm{C}-3^{\prime}\right), 144.8\left(\mathrm{~s}, \mathrm{C}-4^{\prime}\right), 130.5\left(\mathrm{~s}, \mathrm{C}-1^{\prime}\right), 118.4\left(\mathrm{~d}, \mathrm{C}-6^{\prime}\right), 115.0\left(\mathrm{~d}, \mathrm{C}-5^{\prime}\right), 114.4\left(\mathrm{~d}, \mathrm{C}-2^{\prime}\right)$, 99.0 (s, C-10), 95.1 (d, C-6), 93.8 (d, C-8), 80.9 (d, C-2), 66.2 (d, C-3), 27.8 (t, C-4).

Cornoside (7) was obtained as amorphous solid (10 mg) and determined the molecular formula as $\mathrm{C}_{14} \mathrm{H}_{20} \mathrm{O}_{8} \cdot{ }^{1} \mathrm{H}$ NMR (500 MHz, DMSO- $\left.d_{6}\right)$ and ESI-MS $\left(m / z 317[\mathrm{M}+\mathrm{H}]^{+}\right)$data corresponded with the published data [36]. The identification was further supported by ${ }^{13} \mathrm{C}$ NMR (100 MHz, DMSO- $\left.d_{6}\right): \delta 185.3$ (s, C-4), 153.3 (d, C-2), 153.2 (d, C-6), 126.4 (d, C-3), $126.4(\mathrm{~d}, \mathrm{C}-5), 102.8\left(\mathrm{~d}, \mathrm{C}-1^{\prime}\right), 76.8\left(\mathrm{~d}, \mathrm{C}-5^{\prime}\right), 76.6\left(\mathrm{~d}, \mathrm{C}-3^{\prime}\right), 73.3\left(\mathrm{~d}, \mathrm{C}-2^{\prime}\right), 70.0\left(\mathrm{~d}, \mathrm{C}-4^{\prime}\right), 67.3(\mathrm{~s}$, C-1), $63.8(\mathrm{t}, \mathrm{C}-8), 61.0\left(\mathrm{t}, \mathrm{C}-6^{\prime}\right), 39.7(\mathrm{t}, \mathrm{C}-7)$.

\subsection{Determination of Total Phenolic (TPC) and Total Flavonoid Contents (TFC)}

The TPC and TFC of four fractions (DF, EAF, BF, and RWF) and five subfractions (BF-A to E) were measured according to our previously reported method [37]. For TFC, $1.0 \mathrm{~mL}$ of each sample (with the concentration at $1.0 \mathrm{mg} / \mathrm{mL}$ ) dissolved in methanol was mixed with $0.5 \mathrm{~mL}$ of Folin-Ciocalteu reagent in a centrifuge tube and incubated for $1 \mathrm{~min}$. Then, 20\% $\mathrm{Na}_{2} \mathrm{CO}_{3}$ solution $(\mathrm{m} / \mathrm{v})(1.5 \mathrm{~mL})$ and deionized water $(7.0 \mathrm{~mL})$ were added to the tube and kept at $70{ }^{\circ} \mathrm{C}$ in a water bath for $10 \mathrm{~min}$. After being cooled to room temperature, $200 \mu \mathrm{L}$ of the solution was transferred to a 96-well microplate and the absorbance was determined at $765 \mathrm{~nm}$ by a SpectraMax M5 microplate reader (Molecular Devices, Sunnyvale, CA, USA).

For TFC, $1.2 \mathrm{~mL}$ of sample solutions (with the concentration at $1.0 \mathrm{mg} / \mathrm{mL}$ ) were mixed with $0.3 \mathrm{~mL}$ of $\mathrm{NaNO}_{2}(5 \% \mathrm{~m} / \mathrm{v})$ and $3.8 \mathrm{~mL}$ of $70 \%$ aqueous ethanol and incubated for 8 min. Subsequently, $0.3 \mathrm{~mL} 10 \%$ aqueous $\mathrm{Al}\left(\mathrm{NO}_{3}\right)_{3}, 4 \mathrm{~mL} 4 \%$ aqueous $\mathrm{NaOH}$, and $0.4 \mathrm{~mL}$ $70 \%$ aqueous ethanol were added to the mixture and allowed to react at room temperature for $30 \mathrm{~min}$. Then, $200 \mu \mathrm{L}$ of the solution was transferred to a 96-well microplate, for which the absorbance was measured at $510 \mathrm{~nm}$ by using a microplate reader. The TFC and TPC was expressed as milligrams of gallic acid equivalents (mg GAE/g extract) and rutin equivalents per gram of extract (mg RE/g extract).

\subsection{Determination of Antioxidant Activity}

The antioxidant activity of four fractions (DF, EAF, BF, and RWF) and five subfractions (BF-A to E) were evaluated in a combination of DPPH and ABTS radical scavenging assays and FRAP assay based on the method described in our previous study [33]. For DPPH assay, $50 \mu \mathrm{L}$ of the sample solution $(50,100,200 \mu \mathrm{g} / \mathrm{mL})$ was mixed with $0.2 \mathrm{~mL}$ DPPH solution $(0.1 \mathrm{mmol} / \mathrm{L})$ in a $96-$ well plate and allowed to incubate for $30 \mathrm{~min}$. The absorbance was measured at $517 \mathrm{~nm}$ with SpectraMax M5 microplate reader (Molecular Devices, Sunnyvale, CA, USA). For ABTS, $25 \mu \mathrm{L}$ of the sample solution $(50,100,200 \mu \mathrm{g} / \mathrm{mL})$ were added to $0.2 \mathrm{~mL}$ ABTS solution $(7 \mathrm{mmol} / \mathrm{L})$. The mixture was kept in the dark for $6 \mathrm{~min}$, and then, the absorbance was recorded at $734 \mathrm{~nm}$. For FRAP, $20 \mu \mathrm{L}$ sample solution $(50,100,200 \mu \mathrm{g} / \mathrm{mL})$ was mixed with $0.18 \mathrm{~mL}$ of FRAP reagent $(7 \mathrm{mmol} / \mathrm{L})$. After incubating for $10 \mathrm{~min}$ in the dark at $37^{\circ} \mathrm{C}$, the absorbance was determined at $593 \mathrm{~nm}$. All the tests were performed in 
triplicate. The results of DPPH, ABTS, and FRAP values were expressed as $\mu \mathrm{mol}$ Trolox equivalents per gram of extract ( $\mu \mathrm{mol} \mathrm{TE} / \mathrm{g}$ extract).

\subsection{HPLC Analysis}

The BF and compounds 1-7 were analyzed on an Agilent 1260 HPLC system coupled with a diode array detector. Before analysis, the freshly prepared sample solution was filtered through a $0.45 \mu \mathrm{m}$ nylon membrane. The separation was performed using a Reprosil-Pur Basic C18 column ( $5 \mu \mathrm{m}, 4.6 \times 250 \mathrm{~mm}$, Germany) maintained at $35^{\circ} \mathrm{C}$. The injection volume was $5.0 \mu \mathrm{L}$, the flow rate was $1.0 \mathrm{~mL} / \mathrm{min}$, and the detection wavelength was set at $280 \mathrm{~nm}$. The mobile phases were acidified water with $0.1 \%$ formic acid (phase A) and acetonitrile (phase $B$ ), the linear gradient elution was performed as follows: $0-3 \mathrm{~min}$, $20 \% \mathrm{~B} ; 3-10 \mathrm{~min}, 40 \% \mathrm{~B} ; 10-15 \mathrm{~min}, 60 \% \mathrm{~B} ; 15-20 \mathrm{~min}, 100 \% \mathrm{~B}$.

\subsection{Cell Culture and Cell Viability}

Human liver cancer HepG2 cells were purchased from Kunming Cell Bank (Kunming, China). HepG2 cells were grown in DMEM supplemented with $1 \%$ penicillin-streptomycin and $10 \%$ fetal bovine serum in an atmosphere of $5 \% \mathrm{CO}_{2} / 95 \%$ air at $37{ }^{\circ} \mathrm{C}$. When the cells were incubated to an appropriate density (approximately $80 \%$ ), they were treated with positive control $(\mathrm{Vc})$ and the isolated compounds for further experiments.

Cell viability was determined by MTT assay for evaluating the cytotoxicity of each sample [29]. The cells at a density of $1 \times 10^{4}$ cells per well were seeded in a 96-well plate and allowed to incubate for $24 \mathrm{~h}$. Each compound (prepared as four doses from 50 to $200 \mu \mathrm{g} / \mathrm{mL}$ ) was added to each well for $20 \mathrm{~h}$. Then, the cells were treated using MTT solution with a final concentration for $4 \mathrm{~h}$. The medium with MTT was removed, and $200 \mu \mathrm{L}$ of the DMSO was added to dissolve the formazan. The absorbance was recorded at $570 \mathrm{~nm}$ by a microplate reader. The results demonstrated that each compound was nontoxic to HepG2 cells at the tested concentrations.

\subsection{Inhibition of ROS Generation in $\mathrm{H}_{2} \mathrm{O}_{2}$-Induced Hep G2 Cells}

$\mathrm{H}_{2} \mathrm{O}_{2}$-induced HepG2 cells were employed to determine the inhibitory effect on ROS production [3]. HepG2 cells $\left(1.0 \times 10^{5}\right.$ cells per well $)$ were seeded in a 6 -well plate and co-cultured with isolated compounds with $50 \mu \mathrm{g} / \mathrm{mL}$ and $\mathrm{Vc}(8 \mu \mathrm{g} / \mathrm{mL})$. After incubation for $20 \mathrm{~h}$, the medium was removed, and $2 \mu \mathrm{L}$ of $\mathrm{H}_{2} \mathrm{O}_{2}(0.5 \mathrm{mM})$ was added to each well for another $6 \mathrm{~h}$. At the end of experiment, the cells were labeled with $2 \mu \mathrm{L}$ DCFH-DA $(10 \mathrm{mM})$ in the dark at $37^{\circ} \mathrm{C}$ for $20 \mathrm{~min}$. The absorbance was recorded by flow cytometry (Guava easyCyte 6-2L, Millipore, Billerica, Massachusetts, MA, USA).

\subsection{Determination of Cell Apoptosis}

The protective effect of each compound on $\mathrm{H}_{2} \mathrm{O}_{2}$-induced apoptosis of $\mathrm{HepG} 2$ cells was determined using a human annexin VFITC/PI apoptosis kit [38]. HepG2 cells were pre-treated with or without isolated compounds for $48 \mathrm{~h}$. After incubation, $100 \mu \mathrm{L}$ of the binding buffer was added to the cells, and the cells reacted in the dark with $10 \mu \mathrm{L}$ annexin V-FITC for 5 min at room temperature and with $10 \mu \mathrm{L}$ propidium iodide (PI) in an ice bath for $5 \mathrm{~min}$, successively. Cell apoptosis was immediately analyzed using flow cytometry.

\subsection{Statistical Analysis}

All the experiments were performed in triplicate. All the values are expressed as mean \pm standard deviation (SD). The differences within and between the groups were analyzed using one-way analysis of variance (ANOVA) followed by Tukey's test. Difference was considered statistically significant at $p<0.05$. All analyses were performed using Origin 2019b software (OriginLab, Northampton, MA, USA). 


\section{Conclusions}

In this study, different fractions from $A$. fragrans leaves were fractionated, and their TPC and TFC were analyzed. Under antioxidant activity guided isolation, compounds 1-7, including four flavonoid glycosides (1-4) and two flavonoids (5 and 6), were isolated and identified from $A$. fragrans leaves, which suggested that this species is rich in flavonoid compounds. Compounds 2, 5, and $\mathbf{6}$ showed significant antioxidant activity in DPPH, ABTS radical scavenging, and FRAP assays. Furthermore, they visibly prevented the oxidative stress damage through a decrease in ROS content and cell apoptosis in $\mathrm{H}_{2} \mathrm{O}_{2}$ induced HepG2 cells. According to these results, polyphenol compounds, especially flavonoids, have considerable antioxidant capacity because of their phenolic hydroxyl groups. Furthermore, compound 2, possessing the glycoside moiety and three phenolic hydroxyl groups, was the main antioxidant component with the highest content from $A$. fragrans leaves. Compound $\mathbf{6}$ displayed the best antioxidant activity, which may be a major contribution to the activity of $A$. fragrans. Furthermore, the extracts of $A$. fragrans could be served as a feasible natural source of antioxidants in promising health beverages. The study on the compounds from $A$. fragrans leaves suggest that these could be served as antioxidant healthy tea for treating oxidative stress-induced cell damage and could serve as nutritional supplements applied in the food and health industry.

Author Contributions: S.H.: investigation, methodology, data curation, visualization, writingoriginal draft; X.C.: conceptualization, methodology, data curation, visualization, writing-original draft; A.K.: writing—review and editing; Y.L.: formal analysis, writing—review and editing, funding acquisition; Y.W.: visualization; Q.C.: software, data curation, supervision; T.Z.: software, validation; J.C.: resources, supervision; G.C.: conceptualization, methodology, validation, writing-review and editing, supervision, project administration, funding acquisition; All authors have read and agreed to the published version of the manuscript.

Funding: This project was financially supported by Yunnan Major Science and Technology Project in China (2019ZF010), the National Natural Science Foundation of China (31872676 and 32060542) and China Postdoctoral Science Foundation (2020M673586XB).

Institutional Review Board Statement: Not applicable.

Informed Consent Statement: Not applicable.

Data Availability Statement: Data is contained within the article.

Acknowledgments: This project was supported in parts by Yunnan Major Science and Technology Project (Grant No. 2019ZF010) and the National Natural Science Foundation of China (Grant No. 32060542).

Conflicts of Interest: The authors declare no conflict of interest.

Sample Availability: Samples of the compounds are available from the authors.

\section{References}

1. Jiao, Y.; Ji, L.; Kuang, Y.; Yang, Q. Cytotoxic effect of oxaloacetate on HepG2-human hepatic carcinoma cells via apoptosis and ROS accumulation. Neoplasma 2017, 64, 192-198. [CrossRef]

2. Imen, B.E.; Fatma, T.; Abdennacer, B.; Mohamed-Amine, J.; Mohamed, B.; Chokri, M.; Hichem, S. Bioactive compounds from Tunisian Pelargonium graveolens (L'Hér.) essential oils and extracts: $\alpha$-amylase and acethylcholinesterase inhibitory and antioxidant, antibacterial and phytotoxic activities. Ind. Crops Prod. 2020, 158, 112951.

3. Cao, J.; Liu, Y.; Jia, L.; Jiang, L.P.; Geng, C.Y.; Yao, X.F.; Kong, Y.; Jiang, B.N.; Zhong, L.F. Curcumin attenuates acrylamide-induced cytotoxicity and genotoxicity in HepG2 cells by ROS scavenging. J. Agric. Food Chem. 2008, 56, 12059-12063. [CrossRef] [PubMed]

4. Cai, Y.; Luo, Q.; Mei, S.; Corke, H. Antioxidant activity and phenolic compounds of 112 traditional Chinese medicinal plants associated with anticancer. Life Sci. 2004, 74, 2157-2184. [CrossRef]

5. Kim, H.R.; Kim, J.E.; Yun, W.B.; Lee, M.R.; Choi, J.Y.; Park, J.J.; Song, B.R.; Song, H.K.; Hwang, D.Y. Protective effect of oil extracted from Neophocaena asiaeorientalis against hydgrogen peroxide-induced oxidative stress in HepG2 cells. Fish. Sci. 2019, 85, 867-876. [CrossRef]

6. Martin, M.A.; Ramos, S.; Mateos, R.; Granado, S.; Izquierdo-Pulido, M.A.; Bravo, L.; Goya, L. Protection of Human HepG2 Cells against Oxidative Stress by Cocoa Phenolic Extract. J. Agric. Food Chem. 2008, 56, 7765-7772. [CrossRef] 
7. $\quad$ Berson, D.S. Natural antioxidants. J. Drugs Dermatal. 2008, 7, 7-12.

8. Osawa, T.; Namiki, M. Natural antioxidants isolated from Eucalyptus leaf waxes. J. Agric. Food Chem. 1985, 5, 777-780. [CrossRef]

9. Anna, P. Natural antioxidants and antioxidant capacity of Brassica vegetables: A review. LWT-Food Sci. Technol. 2007, 44, 1-11.

10. Xu, D.P.; Zheng, J.; Zhou, Y.; Li, Y.; Li, S. Ultrasound-assisted extraction of natural antioxidants from the flower of Limonium sinuatum: Optimization and comparison with conventional methods. Food Chem. 2017, 217, 552-559. [CrossRef] [PubMed]

11. Benabderrahim, M.A.; Yahia, Y.; Bettaieb, I.; Elfalleh, W.; Nagaz, K. Antioxidant activity and phenolic profile of a collection of medicinal plants from Tunisian arid and Saharan regions. Ind. Crops Prod. 2019, 138, 111427. [CrossRef]

12. Biais, B.; Krisa, S.; Cluzet, S.; Costa, G.D.; Waffo-Teguo, P.; Mérillo, J.M.; Richar, T. Antioxidant and cytoprotective activities of grapevine stilbenes. J. Agric. Food Chem. 2017, 65, 4592-4960. [CrossRef]

13. Noda, Y.; Kaneyuki, T.; Akitane, M.; Packer, L. Antioxidant activities of pomegranate fruit extract and its anthocyanidins: Delphinidin, cyanidin, and pelargonidin. J. Agric. Food Chem. 2002, 50, 166-171. [CrossRef] [PubMed]

14. Wei, H.; Bowen, R.; Cai, Q.; Barnes, S.; Wang, Y. Antioxidant and Antipromotional Effects of the Soybean Isoflavone Genistein. Proc. Soc. Exp. Biol. Med. 1995, 208, 124-130. [CrossRef]

15. Tian, L.; Huang, J.A.; Tian, L.; Huang, J.A. Antioxidant effects of tea catechins on the shelf life of raw minced duck meat. LWT-Food Sci. Technol. 2019, 39, 59-65. [CrossRef]

16. Fuentes, J.; Atala, E.; Pastene, E.; Carrasco-Pozo, C.; Speisky, H. Quercetin oxidation paradoxically enhances its antioxidant and cytoprotective properties. J. Agric. Food Chem. 2017, 65, 11002-11010. [CrossRef]

17. Khan, N.; Mukhtar, H. Multitargeted therapy of cancer by green tea polyphenols. Cancer Lett. 2008, 269, 269-280. [CrossRef] [PubMed]

18. Mehmood, A.; Usman, M.; Patil, P.J.; Zhao, L.; Wang, C. A review on management of cardiovascular diseases by olive polyphenols. Food Sci. Nutr. 2020, 8, 4639-4655. [CrossRef] [PubMed]

19. Silva, R.F.; Poganik, L. Polyphenols from Food and Natural Products: Neuroprotection and Safety. Antioxidants 2020, 9, 61. [CrossRef]

20. Zhang, C.; Suen, L.C.; Yang, C.; Quek, S.Y. Antioxidant capacity and major polyphenol composition of teas as affected by geographical location, plantation elevation and leaf grade. Food Chem. 2018, 244, 109-119. [CrossRef]

21. Yan, Z.; Dingfeng, G.; Simin, L.; Feng, S. Response Surface Optimization of Antioxidant Activity and Composition Analysis of Anneslea fragrans Wall. Bark Soaked Wine. Food Res. Dev. 2020, 41, 72-78.

22. Sun, L.; Hu, X.; Cheng, X.; Luo, L.; Liu, H.; Chen, L. NMR Characterization of Flavanone Naringenin 7-O-Glycoside Diastereomer. Chin. J. Magn. Reson. 2017, 34, 465-473.

23. Huang, H.Y.; Ko, H.; Jin, Y.J.; Yang, S.Z.; Shih, Y.A.; Chen, I.S. Dihydrochalcone glucosides and antioxidant activity from the roots of Anneslea fragrans var lanceolata. Phytochemistry 2012, 78, 120-125. [CrossRef] [PubMed]

24. Yeilada, E.; Tsuchiya, K.; Takaishi, Y.; Kawazoe, K. Isolation and characterization of free radical scavenging flavonoid glycosides from the flowers of Spartium junceum by activity-guided fractionation. J. Ethnopharmacol. 2000, 73, 471-478. [CrossRef]

25. Zhang, H. Theoretical solution of the relationship between the structural activity of flavonoid antioxidants. Sci. China Ser. B 1999, 29, 91-96.

26. Omar, A.M.; Dibwe, D.F.; Tawila, A.M.; Sun, S.; Phrutivorapongkul, A.; Awale, S. Chemical constituents of Anneslea fragrans and their antiausterity activity against the PANC-1 human pancreatic cancer cell line. J. Nat. Prod. 2019, 82, 3133-3139. [CrossRef]

27. Sheiraz, A.B.; Nathalie, M.; Michèle, L. Chemically Synthesized Glycosides of Hydroxylated Flavylium Ions as Suitable Models of Anthocyanins: Binding to Iron Ions and Human Serum Albumin, Antioxidant Activity in Model Gastric Conditions. Molecules 2014, 19, 20709-20730.

28. Aruoma, O.I. Free radicals, oxidative stress, and antioxidants in human health and disease. J. Am. Oil Chem. Soc. 1998, 2, 199-212. [CrossRef]

29. Marian, V.; Dieter, L.; Jan, M.; Milan, M.; Joshua, T. Free radicals and antioxidants in normal physiological functions and human disease. Int. J. Biochem. Cell Biol. 2007, 39, 44-84.

30. Li, X.L.; Zhou, A.G.; Li, X.M. Inhibition of Lycium barbarum polysaccharides and Ganoderma lucidum polysaccharides against oxidative injury induced by $\gamma$-irradiation in rat liver mitochondria. Carb. Polym. 2007, 69, 172-178. [CrossRef]

31. Cui, Q.; Wang, Y.; Zhou, W.; He, S.; Yang, M.; Xue, Q.; Wang, Y.; Zhao, T.; Cao, J.; Khan, A.; et al. Phenolic composition, antioxidant and cytoprotective effects of aqueous-methanol extract from Anneslea fragrans leaves as affected by drying methods. Int. J. Food Sci. Technol. 2021. [CrossRef]

32. Hengartner, M.O. The biochemistry of apoptosis. Nature 2000, 407, 770-771. [CrossRef] [PubMed]

33. Yang, M.L.; Ma, Y.L.; Wang, Z.Y.; Khan, A.; Zhou, W.B.; Zhao, T.R.; Cao, J.X.; Cheng, G.G.; Cai, S.B. Phenolic constituents, antioxidant and cytoprotective activities of crude extract and fractions from cultivated artichoke inflorescence. Ind. Crops Prod. 2020, 143, 111433. [CrossRef]

34. Ling, T. Dihydrochalcones from Symplocos vacciniifolia. Chin. Chem. Lett. 2004, 10, 1182-1184.

35. Antus, S.; Farkas, L.; Gottsegen, Á.; Nógrádi, M.; Strelisky, J.; Pfliegel, T. Dihydrochalcone type sweetening agents. II. The synthesis of some dihydrochalcones. Acta Chim. 1978, 98, 231-240.

36. Li, H.M.; Kim, J.K.; Jang, J.M.; Cui, C.B.; Lim, S.S. Analysis of the inhibitory activity of Abeliophyllum distichum leaf constituents against aldose reductase by using high-speed counter current chromatography. Arch. Pharm. Res. 2013, 36, 1104-1112. [CrossRef] 
37. Fan, Z.; Wang, Y.; Yang, M.; Cao, J.; Khan, A.; Cheng, G. UHPLC-ESI-HRMS/MS analysis on phenolic compositions of different E Se tea extracts and their antioxidant and cytoprotective activities. Food Chem. 2020, 318, 126512. [CrossRef]

38. Zhuang, Y.L.; Ma, Q.Y.; Guo, Y.; Sun, L.P. Protective effects of rambutan (Nephelium lappaceum) peel phenolics on $\mathrm{H}_{2} \mathrm{O}_{2}$-induced oxidative damages in HepG2 cells and D-galactose-induced aging mice. Food Chem. Toxicol. 2017, 108, 554-562. [CrossRef] 